\title{
EchoGéo
}

$31 \mid 2015$

Glocal Ethiopia

\section{Thermidor in Ethiopia? Agrarian Transformations between Economic Liberalization and the Developmental State}

Davide Chinigò et Emanuele Fantini

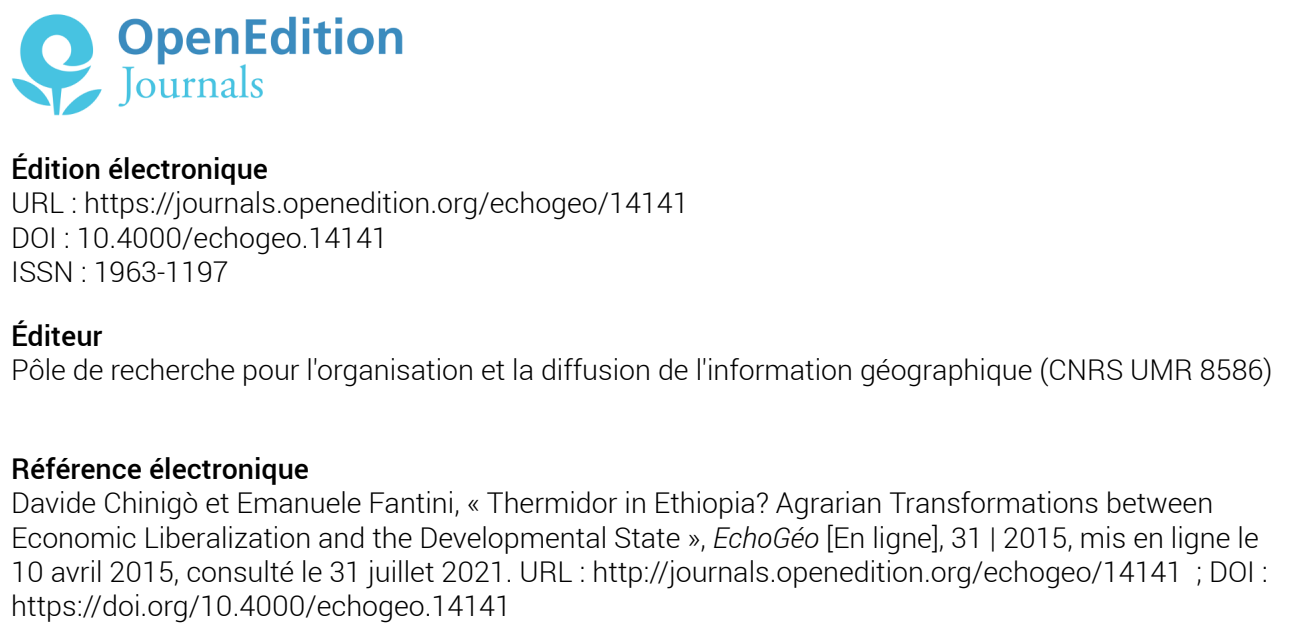

Ce document a été généré automatiquement le 31 juillet 2021.

EchoGéo est mis à disposition selon les termes de la licence Creative Commons Attribution - Pas d'Utilisation Commerciale - Pas de Modification 4.0 International (CC BY-NC-ND) 


\title{
Thermidor in Ethiopia? Agrarian Transformations between Economic Liberalization and the Developmental State
}

\author{
Davide Chinigò et Emanuele Fantini
}

We would like to acknowledge Catherine Dom and two anonymous reviewers for their insightful comments to the first draft of this manuscript. Usual disclaimers apply.

1 In the last years, by virtue of its record of "double digit" GDP growth, Ethiopia has been celebrated among the "African lions" and the "emerging African countries" (McKinsey, 2010; Radelet, 2010). Official statistics set the country on track to meet the ambitious "Growth and Transformation Plan" (GTP), which aims to reach the middle-income status by 2025 (FDRE, 2010). The peculiarity of the Ethiopian case lies in the fact that, unlike other emerging African countries with similar post-revolutionary trajectories, the process of economic growth is not driven by natural resources extraction. On the contrary, the rise of Ethiopian GDP in the last years results from public capital investments in infrastructures and from the improvement of the productivity in the agriculture and manufacturing sectors. These processes have been upheld by emulating the Asian model of the developmental state (Clapham, 2006), implying a key role for the central government in driving and stimulating the national economy, as explicitly theorised by the former PM Meles Zenawi (Zenawi, 2012).

One of the pillars of such development strategy consists in agricultural commercialisation implying significant processes of rescaling and glocalisation (Swyngedouw, 2004). In the GTP the Ethiopian government operated a radical shift in its development strategies: the traditional focus on household agriculture to achieve national food security has become a secondary, although not marginal, objective. This is to embrace market liberalisation strategies to create wealth and employment through the attraction of foreign investments on land, the promotion of micro and small enterprises, as well as of market led agricultural production. 
3 The article addresses the consequences of agrarian transformations in terms of (re)configuration and (re)negotiation of spaces and power in the process of state formation in contemporary Ethiopia. In doing so, we adopt the notion of "Thermidorian situation", developed by Jean-François Bayart as a paradigm to analyse the historical trajectories of post-revolutionary elites consolidating their power in the context of the neoliberal global economy through selective and original strategies of political and economic liberalisation (Bayart, 2008).

4 This perspective elucidates the main argument of the article, i.e. the inherent contradiction of the agrarian policies in contemporary Ethiopia. On the one side, the economic liberalisation and the adoption of market oriented strategies entails processes of rescaling that open up spaces for international flows, for the private sector and for local economic actors. On the other side, the revolutionary ideology and ethos that still animate the Ethiopian ruling class push for a proactive role by the central government in promoting, driving and controlling such processes, with the goals of ensuring compliance to its development vision and of avoiding the emergence of political and economic competitors in gaining legitimacy and support among the population through economic and development initiatives. This contradiction results in ambiguous dynamics of reconfiguration of state intervention in the economy and in the rural spaces, as well as in the on-going negotiation and mediation between the expanding state apparatus and farmers' strategies and aspirations in terms of development and economic success.

5 In order to develop such analysis, the first section of the article applies the Thermidorian paradigm to the analysis of historical and contemporary Ethiopia. The second section analyses the transformation introduced by the new strategy of agricultural commercialization: the reforms of agricultural extensions, the emphasis on agricultural cooperatives, micro-finance institutions (MFIs), and agricultural micro and small enterprises (MSEs). The third section discusses the main tensions of the project for rural transformation by tracing its political, historical and ideological roots back to the 1975 land reform. Particular attention is paid to the post-2001 conjuncture in which the tensions of the contemporary project of rural transformation became much more apparent. ${ }^{1}$ The conclusion analyses the main tensions between the developmental state and economic liberalization within agrarian transformations, highlighting patterns of (re)configuration and (re)negotiation of spaces and power and that apply to the broader process of state formation in contemporary "glocal" Ethiopia.

\section{Thermidor in Ethiopia}

6 In the historical experience of the French Revolution, Thermidor marks the attempt by the revolutionary elite "to get out from the Terror" (Baczko, 2013), transforming itself into ruling class through the institutionalisation of the revolutionary achievements under the Republic, without abandoning their used revolutionary imaginary and vocabulary. This experience inspires the Thermidorian paradigm developed by JeanFrançois Bayart to analyse the historical trajectory of post-revolutionary elites with Marxist or socialist background, professionalising into ruling classes at the time of neoliberal globalisation, upholding their power and accumulating resources through selective and original strategies of economic liberalisation (Bayart, 2008). 
7 This paradigm seems particularly meaningful to grasp the very nature of the process of state formation in contemporary Ethiopia. We refer to the notion of state formation as developed by Bruce Berman and John Lonsdale namely "the historical process, mainly unconscious and contradictory, of conflicts, negotiation and compromises between different groups" (Berman and Lonsdale, 1992, p. 5) that occurs within - and ultimately shapes - the explicit institutional strategies of state building promoted by governments' elites.

8 The Thermidorian paradigm shares with other analysis of post-revolutionary regimes two elements. First, the understanding of these regimes through the analysis of the concatenation of their historical trajectories - the longue durée - with the intimate and personal experience of the former fighters (Clapham, 2012). Second, the attention devoted to the political, cultural and practical factors influencing the processes of institutionalisation of former guerrilla movement into political parties and their legitimacy (De Zeeuw, 2007; Podder, 2014).

However, in respect to these other approaches we just referred to, we retain two elements that in our view constitute the added value of the Thermidorian paradigm in understanding the Ethiopian case. First, the Thermidorian paradigm does not assess the post-revolutionary regimes against the normative approach of "the transition to democracy"; on the contrary it allows highlighting the peculiarity of "a political economy not reducible to the neo-liberal cadre" (Bayart, 2008, p. 53, our translation) and the persistence of the "veil of ideology" (ibid, p. 7). Second, the Thermidorian paradigm situates the analysis of the post-revolutionary political institutions by emphasising their broader relationship with the society. In this respect, combining the Thermidorian paradigm with the notions of "state rescaling" and "glocalisation" (Swyngedouw 2004) allows situating the post-revolutionary political institutions also at different scales - a focus developed in the analysis of case studies such as Cambodia (Bayart, 2008) but not explicitly addressed in the theoretical paradigm.

The process of state building in contemporary Ethiopia has been shaped by the generation of fighters of the Tigray People Liberation Front (TPLF) that since 1991, following the overthrown of the military regime of the Derg, has become the oligarchy leading the ruling coalition of the Ethiopian People Revolutionary Democratic Front (EPRDF). The TPLF revolutionary experience has been institutionalised in the 1995 Constitution, restructuring Ethiopia in a federal and decentralised republic in the name of the right to self-determination of the "nations, nationalities and peoples" of the country (Turton, 2006).

11 The insertion of post-revolutionary Ethiopia in the neoliberal globalisation has been shaped by a selective adhesion to the model of the liberal democracy and free market. The EPRDF distanced itself from liberal democracy, by recalling the revolutionary myth through the official adoption of the "ambiguous doctrine" (Bach, 2011, p. 641) of "revolutionary - abyotawi in Amharic - democracy", hybridising the liberal reforms such us multi-party elections with the political repertoire of the revolutionary front inspired by Marxism, Leninism and Maoism, as well as by ethno-regional ideology. In the field of economic policy, while dismantling the Derg's system of soviet style planned economy, the EPRDF openly rejected the structural adjustments programmes and the macroeconomic policies promoted by the International Financial Institutions, adopting alternative "largely self-determined policies", as described by Joseph Stigltiz, at the time involved in the negotiation on behalf of the World Bank (Stiglitz, 2003, p. 30). Thus 
the Ethiopian government holds a main role or a monopolistic position in key economic sectors like finance, telecommunication and energy, and retains control of the agricultural inputs (land, fertilisers, credit). In this context, the Thermidorian elite consolidates its power by strategies of resources accumulation and control through the straddling of positions within the State administration, the party structure, the NGOs or enterprises affiliated to the EPRDF, and the microfinance and other development institutions controlled by the government.

Three peculiarities of the Ethiopian Thermidor stem from the specificities of the country's historical trajectory. First, the Ethiopian Thermidor results from the overlapping of two different revolutionary moments: the one initiated by the Derg, and the one led by the TPLF and the Eritrean People's Liberation Front (EPLF). ${ }^{2}$ These two revolutions ignited in reaction to the same contradictions of Imperial Ethiopia: on one side the social question related to the issue of land ownership; on the other side the national question, namely the asymmetrical relations between Ethiopia's different ethnic groups. These two questions are strictly correlated. The Derg and the TPLF offered similar answers to the former but diverging to the latter, with TPLF opting for a more radical deconcentration of State institutions at the local level. This entails both elements of rupture and continuity between the two regimes.

Second, the TPLF revolution has been achieved trough a military conquest of power deeply influencing the EPRDF political repertoire. During the fourteen years long armed struggle, the TPLF successfully tested strategies of peasants mobilisation inspired by Leninist and Maoist doctrines. The TPLF acted as vanguard of the rural masses, matching military and political encadrement with the provision of basic social services in the liberated areas of Tigray, thus guaranteeing the political legitimacy and the material support to its struggle. In the Ethiopian Thermidor, these strategies have been hybridised with the technical register of the good governance and the fight against poverty promoted by the international development apparatus, and they have been reproduced through the "capacity building" of the hierarchical state machinery and bureaucratic structures inherited from the previous regimes. This process translates in a political project matching hegemony and coercion, the provision of basic social services and the authoritarian exercise of political power. The EPRDF revolutionary ethos inspire the encadrement of women, youth, and peasants in "development armies" or in the selection of "model villages" and "model farmers" in order to ensure the rigorous implementation of its development policies throughout the country (Lefort, 2012; Seegers et al., 2009).

Third, the polymorphic nature of the revolution contributes to the heterogeneity and internal plurality within the Thermidorian ruling class. While Tigray experienced a real mass revolution-with the whole population involved in the armed struggle (Young, 2006)-in the rest of the country, particularly in its southern marches and peripheral areas, the liberation from the Derg was featured by a rather passive revolution, in Gramsci's terms (Gramsci, 1975), with the TPLF co-opting existing local elites or creating new ones at the end of the war (Vaughan, 2006). Consequently, the reference to the liberation struggles allows various degrees of political legitimation in different Ethiopian regions and peripheries, where the revolutionary myth does not enjoy the same level of cultural significance as it does in Tigray and partially in Amhara. Thus, at local level post-revolutionary development policies mentioned above are shaped by 
processes of negotiation, selected adhesion, or resistance by local elites and ordinary people.

These features contribute to one of the main contradiction of the Ethiopian Thermidor. On one side, the Thermidorian elite sets as its main mission transforming of the country into a mature capitalist system, opening up the economy and the society and implicitly acknowledging the potentialities of economic liberalisation and the role of the private sector. On the other side, the EPRDF-particularly the TPLF oligarchy leading the party coalition-does not fully dismiss the revolutionary ethos and ideology of the political vanguard. Consequently, while in principle acknowledging "society's independence and inertia" (Bayart, 2008)-for instance through ethnic federalism and decentralisation-they seek to control, orient and transform the society according to their ideology and revolutionary plan, preventing the emergence of potential political and economic competitors. These contradictions can be best seen by looking in particular at the processes of rescaling and glocalisation engendered by EPRDF policies of land reform, agricultural commercialisation and market liberalisation in rural areas.

\section{Commercialisation of Smallholder Agriculture in West Arsi: Cooperatives, Micro-Finance Institutions, and Enterprises}

Observations are conducted during several fieldwork visits since 2009 in the West Arsi Zone of Oromiya Region. While some degree of generalisation might apply, different Regions-sometimes even different Districts-have quite diverse policies especially when it comes to implementation. Some of the details presented here have therefore to be considered as contextual and not directly applicable to other Ethiopian contexts.

In recent years, agricultural commercialisation has become one of the most important facets of the government strategy for rural transformation (GTP, 2010), and has entailed the promotion of large-scale investments by public and private actors, as well as commercialised smallholders. While the former has received much international attention, the support to commercialised smallholders is by far central to the notion of Thermidorian situation, as it characterises the processes through which the elite attempt to institutionalize its role of dominant class in the rural areas by means of a selective and partial process of economic liberalization. Thus, support to commercial smallholders is remarkable for at least two additional reasons. First, as noted by Lefort (2012, p. 682), detaching farmers from commercialisation in order to prevent the accumulation of rents was an overriding political priority of the EPRDF-led government since it first came to power in the 1990s. Support to commercial smallholders constitutes by far the most remarkable shift in the government land policy since the 1970s, and has entailed the reformulation of agricultural extensions towards the objectives of economic efficiency and the creation of an environment suitable for market expansion. Second, the support to better-off farmers by means of a strong state intervention is associated with an intense process of institution building at the grassroots level, as well as with the reconfiguration of institutions previously engaged in the support of the smallholder sector as a "homogenous entity" towards a business model. These transformations reflect interventions in the field of microfinance, the cooperative system, and the establishment of micro and small enterprises. 
18 Microfinance has become one of the main government's political priorities to promote fast commercialisation. ${ }^{3}$ Through the Micro-Financing Business Proclamation No. $626 / 2009$, the federal and regional governments have intensified efforts to increase financial services for smallholder farmers and micro and small enterprises (IFAD, 2009). MFIs are closely associated with the regional governments, which are majority shareholders, as well as the ruling party, and they are a central aspect of the government strategy to mobilize the rural population. ${ }^{4}$ The reformulation of credit and financial services to the farmers is also evident in some recent trends characterizing the cooperative system..$^{5}$ Agricultural cooperatives in Ethiopia are formally autonomous, but the local administrative structure/party system complex normally exercises power in cooperatives' formation and their day-to-day activities (Rahmato, 2002). While this interference is not uniform across the country, farmers in West Arsi normally identify cooperatives and MFIs directly with the government.

While until recently the mobilization of the smallholders and endowment of agricultural inputs were the two main functions of agricultural cooperatives, the Agricultural Cooperatives Sector Development Strategy 2012-2016 places agricultural commercialisation at the centre of the cooperative system. Under the new strategy, the cooperatives' 'primary purpose is increasing member producers' production and incomes by helping better link with finance, agricultural inputs, information, and output markets" (FDRE, 2012, p. 9). In remarking the limited involvement in output marketing, the long-term strategic direction for sustaining agricultural commercialisation is enabling the cooperatives to provide two types of marketing services: "selling output on behalf of farmers using robust market information, and having systematic marketing relationships with reliable demand sources" (FDRE, 2012, p. 24). Yet, in order to provide more efficient services to the farmers, strengthening input distribution and marketed output, access to finance is to develop the capacity of the cooperative sector (FDRE, 2012, p. 51). The document expresses the government's commitment to expand the mandate of MFIs and Rural Saving and Credit Cooperatives (RUSACCOs), "to serve the role of a semi-dedicated financing institution for the cooperatives sector" (FDRE, 2012, p. 53). In West Arsi, the new vision on the cooperative sector and the emphasis on MFIs generated two important transformations.

The first transformation concerns the function of MFIs and agricultural cooperatives. Local officials explain that until 2010-11 MFIs and agricultural cooperatives' main task was providing credit for modern agricultural inputs (fertilisers and improved seeds) through credit lines guaranteed by the budget of the regional government. This generated dysfunctions both in terms of mismanagement and non-recovery. More recently, side by side with the diversification of the lines of credit provision, agricultural inputs are no longer given $100 \%$ credit and farmers are required to pay cash for seeds and fertilisers. While many farmers in West Arsi complain about this new system, another recent phenomenon is that the needs assessment, and distribution of inputs and fertilisers, is channelled through the recently established " 1 to 5 networks" (shanee in Oromiya). These are networks of 6 farmers where one is the "model farmer", in charge of assisting the other five with input provisions, introduction to new agricultural techniques. Model farmers are linked to the ruling party structure (Lefort, 2012). Also in West Arsi the majority of the model farmers are party members, and their appointment is approved by the Development Agent of the district agricultural office (ARDO). While no formal document discusses their functions in details, it seems 
that one is channelling credit from MFIs and agricultural cooperatives to the individual farmers, as a way to improve the structural efficiency of input delivery and, at the same time, allowing the local administrative structures, and ultimately the ruling party, to control such process.

The second transformation can be described as a new emphasis with "saving first". Assisting and providing farmers with incentives to form savings groups is among the top priorities behind the strategy of smallholders' commercialisation. In West Arsi this entailed the reformulation and extension of RUSACCOs throughout the countryside. As explained by the Cooperative Desk of the Zone, the new priority is creating stronger linkages between agricultural cooperatives and RUSACCOs, as a way to assist the former "to store post-harvest income for input purchasing the following season". This is aimed to fill the gap in poor areas where access to financial institutions is limited and, in the long run, developing tools to "incentivise savings and scale up innovative instruments such as weather insurance" (FDRE, 2012, p. 20). Extension of RUSACCOs in West Arsi was accompanied by the delocalisation of stores for agricultural inputs (seeds and fertilisers), which since 2012 were established with the ratio of one in every four kebeles. Agricultural cooperatives are required to save at least $30 \%$ of their net income in the Commercial Bank of Ethiopia.

The relationship between "saving first" and commercialisation of smallholder agriculture becomes even more significant when it comes to some recent trends seeing the promotion of micro and small enterprises (MSEs) in the field of agriculture. This sector has been a priority of the government since the Issuance of National Micro and Small Enterprises Strategy in 1997 and the establishment of the Federal Micro and Small Enterprises Development Agency. Their development is seen as an important instrument to create a productive and dynamic private sector, creating long-term jobs, and providing the basis for medium and large export-oriented enterprises. MSEs are supported through infrastructural and financial facilities, trainings, and supply of raw materials (Ageba and Ameha, 2004).

However, more recently MSEs have been actively promoted in the agricultural sector. Their emergence must therefore be contextualised with the new priority of agricultural commercialisation, ${ }^{6}$ and today MSEs offices have been established at regional, zone, and wereda levels. The zone MSEs officer for West Arsi explains that enterprises are meant to create new jobs in the rural areas, particularly among landless youth and women. They are aimed at reducing poverty through the creation of businesses both in and out agriculture. Start-ups can be established with no capital and by presenting business plans to MFIs, most notably the OCSSCO. The enterprise can be formed if the promotion office considers the business of the start-up "successful". At this stage members of the "micro" enterprise have to provide for $20 \%$ of the initial capital, while are allowed to demand for up to $80 \%$ credit from MFIs. "Micro" enterprises possess a capital of up to 50000 ETB and employ between 5 and 30 workers; beyond that they "graduate" and achieve the status of "small enterprise". MSEs are required to save in a bank account $20 \%$ of their profit, whose re-investment has then to be negotiated with the promotion office and the MFI providing the initial loan. Agricultural MSEs in West Arsi have to fit one of the sub-sector priorities identified by the zone promotion office. These include horticulture, cattle fattening, animal feedstock production, irrigated agriculture, bee keeping, and afforestation. One important aspect of the current development of MSEs is that they can demand the allocation of land when this is required to discharge their 
activities. Requests are submitted to the wereda MSEs office that, in collaboration with the ARDO, is in charge of allocating plots from the wereda "Land Bank". In Siraro wereda this for instance entailed the redistribution of previously communal land in Damine kebele to several MSEs for irrigated horticulture. This kebele is located on the bank of Bilate River and is particularly suitable for irrigated crop production. While the kebele leader received complaints from herders previously using this communal land for pasture, he noted that this is the only way for landless youth to access to land and starting new businesses that can leverage the local economy.

It is still too early to assess the impacts of these reforms, however it seems clear enough that they are likely to entail profound transformations in rural Ethiopia. While some farmers will benefit from increased commercialisation-by getting land through rental arrangements or support from MFIs, and by their relative position vis-à-vis local power-social stratification is normally associated to increased inequalities reproducing marginality and ultimately poverty. In the final part of this article, our purpose is reconstructing the background to the current relationship between agrarian transformation and state formation, and contextualising the current Thermidorian situation in the longer view.

\section{Agrarian Transformation and State formation in Ethiopia}

The question of land has always been central to the Ethiopian project of state formation (Markakis, 2011). During the Imperial period (up to 1974) the provision of land grants to the military was the main mechanism through which the Abyssinian empire secured the control over the southern, western and eastern peripheries of the country. While this gave rise to a deeply exploitative system of landlord-tenant relations, the legacy of this controversial history of domination culminating in the subjugation of the societies over time incorporated into the Empire is still today one of the main facets of what the historiography defines as the Ethiopian "national question" (Turton, 2006). In the Imperial period this was reflected in a hierarchical system of distribution of political power along the lines of centre/periphery relations, at the heart of which lay the question of land redistribution. This question was partly fulfilled by the 1974 revolution, when the military junta known as Derg went to power through the political slogans "land to the tiller" and "Ethiopia First". In 1975 the Derg regime implemented a radical project of land nationalisation that phased out the Imperial landed classes, and provided for the redistribution of the land through the newly established Peasant Associations. While for a few years the redistribution satisfied the needs of a land hungry peasantry, particularly in the lowland periphery of the country, the adoption of a rigid socialist economic model generated a new set of problems soon after (Clapham, 1988). The 1975 land reform had far-reaching consequences on the political and socioeconomic relations in Ethiopian rural areas. Beside the socialisation of agricultural practices, it mandated that producer and service cooperatives to be set-up, the suppression of free market and private trade, and made space for Agricultural Marketing Corporations (Jemma, 2001). Whereas the economic impacts of the reform were disastrous, with declining productivity and increasing food shortages, from a political point of view the territorialisation of state rule in the rural milieu reached levels never experimented before. Since then, the Peasant Associations-later on 
known as kebele-became intimately tied to the party structure and a comprehensive system of political and socio-economic control of the rural areas was established throughout the country. deconcentrated architecture of the Federal Republic. The 1994 Ethiopian Constitution, and the 1997 Land Law, empowers the National Regional States with the bulk of land administration prerogatives. In the 1990s the policy document guiding the government approach to rural development was the Agriculture Development-Led Industrialization Strategy (ADLI). Under ADLI, state support to smallholder agriculture is aimed at achieving the objective of national food self-sufficiency, which in the long run would also create the conditions for other sectors of the economy, particularly industry, to develop. Land policy is also a central aspect of the programme of decentralization implemented by the EPRDF since the 1990s. In the 1990s the implementation of decentralization entailed the territorialisation of state rule towards ethnically defined entities, reflecting the government priority of establishing or "giving a shape" to Ethnic Federalism. In the 2000s decentralization focused on the deconcentration of prerogatives and resources to the local administrative structures, through the so-called wereda-level decentralization. It is in this context-and after a turbulent political phase that saw in 2001 the purge of the TPLF's "left-wing" and in 2005 the most controversial elections in the history of the country (Lefort, 2007)-that the 2005 Land Law provides for further deconcentration of prerogatives on land administration to the local administrative structures of the wereda and kebele, and establishes the conditions for a strategy of agricultural commercialisation that in the 1990s the EPRDF saw with scepticism.

The policy document outlining the new strategy for agricultural commercialisation is the 2010 GTP. In covering the years between 2010 and 2014, the GTP is the third poverty reduction strategy paper adopted by the government of Ethiopia after the Sustainable Development and Poverty Reduction Program (2002-2005) and the Plan for Accelerated and Sustained Development to End Poverty (2005-2010). Under the GTP the "agricultural strategy will direct on placing major effort to support the intensification of marketable farm products -both for domestic and export markets, and by small and large farmers" (GTP, 2010, p. 8). Large-scale commercial agriculture and commercialization of smallholder farming are equally supported, as the latter "will continue to be the major source of agricultural growth" (GTP, 2010, p. 8). Agricultural commercialisation is the main political priority for fast rural transformation, and towards making Ethiopia a middle-income country by 2025. Achieving food security through the direct support of the smallholder sector becomes a secondary, although not marginal, priority. Since the end of the 1990s another important pillar of the strategy for commercialisation is the Rural Land Registration Programme.

These reforms reflect a land policy framed around three main priorities. The first is commercialised agriculture by successful smallholders, some of whom manage to actually accumulate land through sharecropping, renting, and/or direct support.

EchoGéo, 31 | 2015 
Second, large-scale commercial agriculture by means of involving the private sector is promoted on what the government defines as "unused land". While the notion of "unused land" is largely constructed, "Land Banks" have been established at both Federal and Regional levels. Districts are required to provide a list of the "unused" land suitable for large-scale commercial agriculture, and then the Regional and Federal governments are in charge for allocation to private (foreign and domestic) investors and stipulate leases accordingly. The third priority is constituted by less successful farmers, whom are mainly targeted through food security initiatives. Agricultural extensions to these areas are provided through the Food Security Programme (FSP), which is composed of four main components: the Productive Safety-Net Programme (PSNP); the Household Asset Building Programme (HABP); the Complementary Community Investment (CCI); and the Resettlement component.

The strategy for agricultural commercialisation is nonetheless framed differently in different regions, revealing the tensions and contradictions inherent to the ongoing process of state formation. In the country's "highland centre" and to some extent "highland periphery", where smallholders constitute the main power base of the ruling party - and where the post-revolutionary narrative remains a meaningful legitimating discourse - the land policy is mainly driven by the first and third priorities. ${ }^{7}$ In the "lowland periphery", where the state apparatus is less consolidated and often actively challenged - these regions having being incorporated in the ethnic federal structure mainly through a "passive revolution" - the government priority is mainly encouraging large-scale commercial agriculture by means of involving foreign and local private investors (Makki, 2012).

Contemporary agrarian transformations in Ethiopia reflect a dynamic of "glocalisation" to the extent that agricultural commercialisation is implemented by means of rescaling normative arrangements at supra-national level-through the selective involvement of global capital in large-scale commercialisation-as well as downwards to regions, wereda, and kebele-through the support to commercialised smallholders. The peculiarity of the Ethiopian case is that the land policy-and in the context of this article the agenda for commercialisation-is intimately connected to the project of state building, as it reflects the attempt of the ruling elite to institutionalise its power by means of the territorialisation of state rule in the rural milieu, and by an increasing involvement of global capital. In this paper we characterise this sequence as a Thermidorian situation, whereby in the eyes of the ruling elite sustaining fast agricultural growth through commercialisation is the only viable solution to sustain the country's transformation in the long run. This reflects a fluid dynamic of postsocialist transition. Yet, the changing agenda for rural development from national food self-sufficiency to commercialisation shows that in the Ethiopian Thermidor, the ruling elite has not only an exclusive interest in preserving the power acquired during the revolution. Rather, political and historical conditions make the elite active in designing radical projects of rural transformation in order to fulfil the expectations raised by the revolutionary process. This is not without tensions and contradictions. The most important one, in the context of this paper, is the ambiguity of the project of rural transformation vis-à-vis the question of land. While maintaining a system of state ownership that guarantees the ruling party with greater leverage over land allocation, resource distribution and control of the countryside, agricultural commercialisation is underpinned by a project of social engineering with clear political objectives. This reflects an on-going dynamic of state formation to the extent that the negotiation of 
land and local resources becomes central to the constitution of citizenship in the rural areas. Yet, the rural space is fluid and constantly re-constructed by means of opposing, and often contradictory, normative frameworks. Liberal concerns about strengthening tenure security and sustaining market development by means of involving the private sector, intervene into a context where the state, and particularly the local administrative structures, has increasing powers over land and resources allocation. People negotiate the rural space by trying to validate their claims to land and natural resources through these overlapping, although sometimes incompatible, normative systems and, depending on their relative position vis-à-vis the local power, elaborate, challenge or contest the political project behind it.

\section{Conclusion}

The Thermidorian paradigm points at the need to understand the significance of contemporary processes of rescaling and glocalisation linked to agrarian transformations and the shift towards agriculture commercialization in light of the specificities of Ethiopia's post-revolutionary historical trajectory. On the other side, the notion of glocalisation recalls the need to situate the analysis of the Thermidorian situation within the specificities of different Ethiopian regions and peripheries, where the post-revolutionary narrative enjoys different degree of political legitimacy and popular support. Taking into account both historical and geographical specificities allows to highlight the central role that agrarian transformations and land issues play in the process of state formation in Ethopia, influencing the asymmetrical power relationships between different scales, social and ethnic groups in the country.

The Ethiopian Thermidor results from the overlapping of two different revolutions, the one of the Derg and the one of TPLF, both addressing these issues with similar and diverging answers. Thus, this overlapping entails both elements of continuity and rupture between the two regimes in the reconfiguration of the rural space, through land management, agricultural policies and institutions like farmers' cooperatives.

In contemporary post-revolutionary Ethiopia, the solutions offered by the Thermidorian elite to these issues are marked by a shift towards economic liberalisation and agricultural commercialisation. In theory, these policies imply a process of glocalisation in two directions: $i$ ) by opening for foreign investments in land and agriculture, especially in the country's periphery, where the reach of the state is less comprehensive and smallholders do not constitute EPRDF main constituency; ii) by encouraging at local level farmers cooperatives and Micro and small enterprises, oriented towards agricultural commercialization. However, in the practice, these processes of glocalisation do not entail the loosing of influence and power by the central state in favor of global or local actors. On the contrary, in the name of the developmental state, these policies involve a reconfiguration of the government intervention in rural areas and the agricultural sector, resulting in an even stronger influence of the state. This is achieved trough the reactivation of rural institutions inherited from the previous regimes like cooperatives, the control of allegedly neutral and technical ones like MFIs or the promotion of new "neoliberal" ones, such as micro and small enterprises.

The tension between these two aspects of the same agrarian policy stems from the inherent contradiction featuring the economic liberalisation under the Ethiopian 
Thermidor. On one side, the Thermidorian elite aspires at transforming Ethiopia into a "mature capitalist system", promoting economic liberalisation, adopting market oriented logics and acknowledging the role of the private sector. The material results of these endeavours are tangible in terms of structural economic transformation and social diversification. On the other side, the impact of these changes does not seem fully acknowledged by the oligarchy leading the EPRDF. The revolutionary ethos that still inspires them fails to fully recognize "the independecy and inertia of society" (Bayart, 2008), impling a role for the ruling party and the developmental state as political vanguard that should orient, lead and encadre the population and control the country resources towards the achievement of the desired developmental outcomes. Economic endeavours by private "glocal" actors are therefore accepted and supported as long as they fit in this schema and do not emerge as potential competitors to the government.

In the fast growing and "emerging" Ethiopia, economic considerations seem therefore subordinated to political and ideology imperatives. Thus, economic liberalisation under the Ethiopian Thermidor nurtures increasing aspirations on development, wealth and upgrade mobility by the population. At the same time, it compels citizens to comply with the decisions taken by an expanding state apparatus in order to see their claims to resources validated. This schizophrenia casts shadows on the effectiveness and sustainability of EPRDF economic policies, and ultimately on the political legitimacy of this development project, if we acknowledge its main ideologue, the late PM Meles: "I am convinced that we will cease to exist as a nation unless we grow fast and share our growth". ${ }^{8}$

\section{BIBLIOGRAPHIE}

Ageba G., Ameha W., 2004. Micro and Small Enterprises Development in Ethiopia: Survey Report. Ethiopian Development Research Institute, Research Report II.

Bach J., 2011. Abyotawi democracy: neither revolutionary nor democratic, a critical review of EPRDF's conception of revolutionary democracy in post-1991 Ethiopia. Journal of Eastern African Studies, 5 (4), p. 641-663.

Baczko B., 2013. Comment sortir de la Terreur: Thermidor et la Révolution. Paris, Gallimard.

Bayart J.-F., 2008. Le concept de situation thermidorienne: régimes néo-révolutionnaires et libéralisation économique. Questions de recherche, 24, p. 1-77.

Berman B., Lonsdale J., 1992. Unhappy Valley: Conflict in Kenya and Africa. James Currey, Eastern African Studies.

Clapham C., 2012. From liberation movement to government. Past legacies and the challenge of transition in Africa. The Brenthurst Foundation, Discussion paper 8/2012.

Clapham C., 2006. Ethiopian development: The politics of emulation. Commonwealth \& Comparative Politics, 44 (1), p. 137-150. 
Clapham C., 1988. Transformation and Continuity in Revolutionary Ethiopia. Cambridge, Cambridge University Press.

Deribie E., Nigussie G., Mitiku F., 2013. Filling the breach: Microfinance. Journal of Business and Economic Management, 1 (1), p. 10-17.

De Waal A., 2013. The theory and practice of Meles Zenawi. African Affairs, 112 (446), p 148-155.

De Zeeuw J. (ed.), 2008. From soldiers to politicians: Transforming rebel movements after civil war. Boulder, Lynne Rienner Publishers.

Federal Democratic Republic of Ethiopia (FDRE), 2012. Agricultural Cooperatives Sector Development Strategy. Addis Ababa, Agricultural Transformation Agency.

FDRE, 2010. Growth and Transformation Plan (GTP). Addis Ababa, Ministry of Finance and Economic Development (MOFED).

Gramsci A., 1975. Quaderni dal carcere. Torino, Einaudi Editore.

Jemma J., 2001. The Debate over Rural Land Tenure Policy Options in Ethiopia: Review of the Post-1991 Contending Views. Ethiopian Journal of Development Research, 23 (2).

IFAD. 2009. Country Programme Evaluation. International Fund for Agricultural Development, Federal Democratic Republic of Ethiopia, Report No. 2045-ET.

Lefort R., 2012. Free Market Economy, 'Developmental State' and Party-State Hegemony in Ethiopia: the Case of the 'Model Farmers'. Journal of Modern African Studies, 50 (4), p. 681-706.

Lefort R., 2007. Powers - Mengist - and Peasants in Rural Ethiopia: the May 2005 Elections. Journal of Modern African Studies, 45 (2), p. 253-273.

Makki F., 2012. Power and property: commercialization, enclosures, and the transformation of agrarian relations in Ethiopia. Journal of Peasant Studies, 39 (1), p. 81-104.

Markakis J., 2011. Ethiopia. The Last Two Frontiers. Oxford, James Currey.

McKinsey Global Institute, 2010. Lions on the move: the progress and potential of African economies. Washington DC, McKinsey Global Institute.

Podder S., 2014. Mainstreaming the non-state in bottom-up state building: linkages between rebel governance and post-conflict legitimacy. Conflict, Security \& Development, 14 (2), p. 213-243.

Negash T., Tronvoll, K., 2000. Brothers at war: making sense of the Eritrean-Ethiopian war. Oxford, James Currey.

Pool D., 2001. From guerrillas to government: the Eritrean People's Liberation Front. James Currey, Athens.

Radelet S., 2010. Success Stories from 'Emerging Africa' Journal of Democracy 21 (4), p. 87-101.

Rahmato D., 2002. Civil society organizations in Ethiopia. In: S. Pausewang, K. Tronvoll, and L. Aalen, eds. Ethiopia Since the Derg: A Decade of Democratic Pretension and Performance. London, Zed Books, p. 103-119.

Segers K., Dessein J., Hagberg S., Develtere P., Haile M., Deckers J., 2009. Be like bees-the politics of mobilizing farmers for development in Tigray, Ethiopia. African Affairs, 108 (430), p. 91-109.

Stiglitz J.-E., 2003. Globalization and its Discontents. London, Norton Paperback.

Swyngedouw E. 2004. Globalisation or 'glocalisation'? Networks, territories and rescaling. Cambridge Review of International Affairs, 17 (1), p. 25-48. 
Tadesse M., Young J., 2003. TPLF: reform or decline? Review of African Political Economy, 30 (97), p. 389-403.

Turton D. (eds.), 2006. Ethnic Federalism: the Ethiopian Experience in Comparative Perspective. Oxford, James Currey.

Vaughan S., 2006. Responses to Ethnic Federalism in Ethiopia's Southern Region. In D. Turton, eds. Ethnic federalism: The Ethiopian experience in comparative perspective. Oxford, James Currey.

Vaughan S., Tronvoll K., 2003. The Culture of Power in Contemporary Ethiopian Political Life. Stockholm, SIDA.

Young J., 2006. Peasant Revolution in Ethiopia: The Tigray People's Liberation Front, 1975-1991. Cambridge, Cambridge University Press.

Zenawi M., 2012. State and markets: neoliberal limitations and the case for a developmental state. In A. Noman, K. Botchwey, H. Stein, J. Stiglitz, eds. Good Growth and Governance in Africa: Rethinking development strategies. Oxford Oxford University Press.

\section{NOTES}

1. In 2001 an internal and rather obscure conflict between the oligarchy of former fighters leading the TPLF led to the purge of the most radical and left-wing component and to the consolidation of power within the inner circle of the Prime Minister and TPLF chairman Meles Zenawi (Taddesse and Young, 2003). In the political "renewal" that followed that event, EPRDF officially inspired its economic policies to the emulation of the Asian "developmental state" model, with an increased orientation towards market economy and the transformation of the country in a mature capitalist system.

2. The TPLF and the EPLF were allied in the armed struggle against the Derg, in the name of the autonomy of the bordering regions of Tigray and Eritrea. At the time, the latter was a province of Ethiopia and seceded at the end of the civil war, becoming an independent state in 1993. The EPLF became Eritrea's ruling party, following a "thermidorian" trajectory parallel to the one of the TPLF (Pool, 2001). The legacy of the ambiguous relations between the two fronts during the armed struggle, and their unsolved ideological and personal disputes, were among the factors fuelling the Ethio-Eritrean war of 1999-2001 (Negash and Tronvoll, 2000).

3. Microfinance was first regulated by the Proclamation No. 40/1996, which provided microfinance institutions to be regulated by the National Bank of Ethiopia and to be owned by Ethiopian nationals only. The proclamation led to the establishment of the Association of Ethiopian Microfinance Institutions (AEMFI) in 1999.

4. The three main MFIs are the Amhara Credit and Saving Institution (ACSI), the Dedebit Credit and Saving Institution (DECSI) [Tigray], and the Oromia Credit and Savings Share Company (OCSSCO), altogether accounting for $74 \%$ of the market share in terms of loan provision (Deribie et al., 2013).

5. Cooperatives in Ethiopia were first introduced in the 1960s during the Imperial period through two consecutive decrees, the Farm Workers' Cooperative Decree No. 44/1960, and the "Cooperative Societies Proclamation No. 241/1966". However, their function as a political instrument to mobilize the peasantry has to be contextualised in the reform of the local administrative structures during the Derg (Proclamation No. 138/1978), when the forced formation of producer cooperatives was implemented side by side with the establishment of Peasant Associations. In 1998 the EPRDF-led government enacted the Cooperative Society Proclamation No. 147/1998, which is the framework legislation ruling the cooperative system 
today, and providing for four cooperative levels: primary cooperatives, unions, federations, and a national cooperative league. While the organization of primary cooperatives varies from region to region, they normally serve one or several kebeles, whereas unions serve multiple weredas or an agricultural zone.

6. In West Arsi there is no evidence of agricultural MSEs until 2010.

7. Markakis (2011, p. 12-15) categorises centre-periphery relations by distinguishing between 'highland centre', 'highland periphery', and 'lowland periphery'.

8. Quoted in De Waal (2013).

\section{RÉSUMÉS}

L'article analyse les récentes politiques foncières mises en place par le gouvernement Éthiopien pour promouvoir la commercialisation agricole, dans la perspective de la trajectoire historique de formation de l'État Éthiopien et à partir du paradigme des "situations thermidoriennes " développé par Jean-François Bayart. L'idée d'un Thermidor Éthiopien éclaircit les stratégies originales et sélectives de libéralisation politique et économique adoptées par une élite postrévolutionnaire qui cherche à consolider son pouvoir à l'époque de la globalisation néolibérale.

Les contradictions de ces stratégies pour ce qui concerne le foncier sont approfondies à travers l'étude des réformes de modernisation agricole, des coopératives agricoles, des institutions des micro-finances et des micro et petites entreprises agricoles dans la zone de West Arsi (région Oromia). Ces transformations agricoles sont caractérisées par une dynamiques sélective et incomplète de libéralisation, au nom du developmental state, et demeurent au cœur du processus de formation de l'État Éthiopien contemporain, à travers des processus de (re)configuration et (re)négociation des espaces et du pouvoir.

The article contributes to the debate about the historical trajectory of state formation in Ethiopia and, by employing the notion of Thermidorian Situation as developed by Bayart, discusses some recent shifts in the land policy towards agricultural commercialization. The Ethiopian Thermidor sheds light on the extent to which post-revolutionary elites since the 1990s have adopted selective and original strategies of political and economic liberalization to consolidate their power in the context of neoliberal globalization. The article's main argument-that contemporary agrarian policies in Ethiopia are inherently contradictory-is elucidated through empirical details on recent reforms of agricultural extensions, cooperatives, micro-finance institutions (MFIs), and agricultural micro and small enterprises (MSEs) in the case study of West Arsi Zone (Oromia Region). The article concludes that the current agrarian transformation in Ethiopia, characterized by selective and incomplete dynamics of liberalization under the developmental state, remains by far central to the overall process of state formation and can be best described through unfolding patterns of (re)configuration and (re)negotiation of spaces and power. 
INDEX

Mots-clés : Éthiopie, formation de l'État, agriculture, terre, élites postrévolutionnaires

Keywords : Ethiopia, state formation, agriculture, land, post-revolutionary elites

\section{AUTEURS}

\section{DAVIDE CHINIGÒ}

Davide Chinigò, davide.chinigo@unibo.it, is Research Fellow in "State, Plurality, Change in Africa", Centre for Historical and Political Studies on Africa and the Middle East Department of Political and Social Sciences Alma Mater Studiorum, University of Bologna, Italy

\section{EMANUELE FANTINI}

Emanuele Fantini, emanuele.fantini@unito.it, is Research fellow, University of Turin, Department of Cultures, Politics and Society. She published:

- Fantini E., Puddu L., 2015, in press. Ethiopia and international aid: a history of high modernism, donors' plurality, and exceptional measures. In Hagmann T., Reinters P. (eds.), Development without democracy. How foreign aid contributes to authoritarian regimes in Africa. Zed Books.

- Fantini E., 2015, forthcoming. Crafting Ethiopia's glorious destiny. Pentecostal and economic transformation under a developmental state. North East African Studies.

- Fantini E., 2013. Transgression and acquiescence: the moral conflict of Pentecostals in their relationship with the Ethiopian State. PentecoStudies, Vol. 12, n. 2. 